\title{
Demokrasi Pada Pilkada Serentak 2020 di Era Pandemi Covid-19
}

\author{
Else Auvi Dalilah \\ IIK Strada Indonesia \\ elseauvi0@gmail.com
}

\begin{abstract}
Abstrak
Indonesia adalah negara demokrasi yang menghadapi tantangan di masa pandemi. Kegiatan pilkada yang mulanya dilaksanakan di pertengahan tahun 2020, harus ditunda hingga akhir tahun tepatnya dibulan Desember karena beberapa pertimbangan. Pemerintah yang terdiri dari Kementrian Dalam Negeri, DPR, KPU, dan Bawaslu telah sepakat melaksanakan pemilu ditengah pandemi Covid-19. Pertimbangan tersebut diambil karena sebanyak 270 daerah perlu dipimpin kepala daerah yang mempunyai legitimasi kuat untuk mengawal kebijakan baru dalam menanggapi pandemi Covid-19 di masing-masing daerah. Selain itu pro dan kontra terjadi dimasyarakat, sebagian masyarakat tidak setuju dengan kebijakan pemerintah terkait pelaksanaan Pilkada ditengah wabah covid-19. Namun optimisme pemerintah perlu mendapatkan dukungan masyarakat dan semuah pihak terkait untuk menyukseskan pelaksanaan pilkada 2020. Pelaksanaan pilkada ditengah pandemi membutuhkan dukungan banyak pihak terutama dari segi anggaran, disiplin protokol kesehatan oleh penyelenggara dan peserta pilkada serta partisipasi politik pemilu.
\end{abstract}

\section{Latar Belakang}

Sebagai negara yang menganut asas demokrasi, penting bagi warga Indonesia memiliki proses untuk memilih orang dalam mengisi jabatan-jabatan politik, proses tersebut dikenal dengan sebutan pemilu. Pemilu merupakan salah satu pesta demokrasi terbesar di Indonesia. Disetiap berjalanya pemilu, hampir dipastikan terdapat sebagian besar permasalahan yang terjadi. Baik itu faktor internal maupun faktor eksternal yang menghambat berjalanya pemilu. Pemilihan kepala daerah pada tahun 2020 berbeda dengan Pilkada pada tahun-tahun sebelumnya, karena ini pertama kali dilaksanakan pemilu ditengah-tenagh pandemi Covid19. Pemerintah dengan disigap memikirkan dan mengantisipasi supaya pilkada ini harus tetap terlaksana, Pilkada sempat diundur, sebelumnya direncankan pada tanggal 23 September 2020 lalu diundur sampai tanggal 9 Desember 2020. Sesuai dengan keputusan KPU, Bawaslu, Pemerintah dan DPR. Pelaksanaan Pilkada serentak pada tahun 2020 membutuhkan waktu untuk mempersiapkan dan melaksanakan Pilkada dengan protokol kesehatan Covid19. Ditakutkan akan menurunya kualitas Pilkada dan keterwakilan pemilihan tidak maksimal, ditambah dengan bertambahnya pasien yang tertular atau terkena virus Covid-19, hal tersebut menambah kekawatiran dalam pelaksanaan Pilkada. Dengan adanya Pandemi Covid-19 menyebabkan kurang maksimal dan ditakutkan akan membatasi kinerja pelaksana Pilkada dan juga akan berimbas pada pelaksaan Pilkada itu sendiri.

Dengan situasi demikian tertunya berpengaruh terhadap berjalanya pesta demokrasi Indonesia. Agenda pelkasaan pemilihan Kepala Daerah di 270 daerah ikut terkena imbas karena pandemi. Di sisi lain muncul berbagai reaksi publik baik dari organisasi masyarakat, pemerintah pemilu, maupun tokoh yang meminta supaya pelaksanaan pilkada ditunda demi menjaga keselamatan dan keamanan warga. Rekasi penundaan tersebut sebagai wujud 
keprihatinan dengan bertambahnya jumlah terkonfirmasi positif Covid-19 diberbagai daerah di Indonesia.Pilkada di masa pandemi Covid-19 dikhawatirkan dapat menurunkan minat pemilih dari masyarakat, hal tersebut bertentangan dengan tujuan pelaksanaan Pilkada itu sendiri, karena dalam Pilkada selain mencari pemimpin bagi masyarakat, dibutuhkan suara dan peran masyarakat dalam pemilihan. Jika Pilkada dilaksanakan ditengah pandemi Covid19 kemungkinan masyarakat enggan untuk datang ke TPS karena rasa khawatir terhadap virus Covid-19.

Hal tersebut dapat menimbulkan kecurangan dalam perolehan suara dimana ditakutkan akan meningkatnya masyarakat memilih golput, sehingga dikhawatirkan dapat disalah gunakan hak suara masyarakat yang tidak menggunakan hak suaranya. Tahapan pelaksaan pilkada serentak tahun 2020 dapat dilaksanakan tetapi pelaksanaan Pilkada harus mengedepankan kepatuhan dan ketegasan aparat dalam penerapan protokol kesehatan. Covid19 bukan untuk dihindari, tetapi ditangani dengan baik dan tepat. Kampanye ditahun sekarang berbeda dengan kampanye pada tahun-tahun sebelumnya, dengan adanya pembatasan fisik, para calon pemimpin harus lebih kreatif dan inovatif dalam melaksankan kampanye di masa pandemi.

Prosedur pelaksanaan Pilkada di masa pandemi, aturan mengenai protokol kesehatan pada pilkada serentak diatur dalam peraturan KPU nomer 6 tahun 2020. Secara khusus, tata cara pemungutan suara diatur pasal 71-74 PKPU tersebut. Beberapa aturan perubahan yakni mengenai jumlah pemilih disetiap TPS yang semulanya maksimal 800 orang/TPS menjadi 500 orang. Ada beberapa aturan waktu pemilihan yang dijadwalkan KPU pertiap jamnya hal itu bertujun untuk mengurangi jumlah kerumunan. Selain itu beberapa protokol yang harus diperhtikan adalah :

- Mencuci tangan dengan air

- Pemeriksaan suhu tubuh

- Menjaga jarak

- Menggunakan sarung tangan sekali pakai yang telah disediakan oleh KPU

- Kewajiban memakai masker

- Pemberian tetesan tinta oleh petugas KPPS.

\section{Kasus/ Masalah}

Badan Pengawas Pemilu (Bawaslu) menemukan permasalah yang terjadi di 122.700 tempat pemunguta suara (TPS) pada pilkada serentak 2020. Hal ini merupakan laporan yang dikirim pengawas pemilu melalui aplikasi Sistem Informasi Pengawasan Pilkada (Siwaslu). Anggota bawaslu Mochammad Afifuddin merinci jumlah permasalahan yang terjadi yakni, perlengkapan pemungutan suara yang kurang dari 1.803 TPS, tidak terdapat fasilitas cuci tangan di 1.454 lokasi TPS, DPT tidak terpasang di 1.727 TPS, dan informasi tentang pasangan calon yang tidak dipasang sebanyak 1.983 TPS. Ditemukan Kelompok Penyelenggara Pemungutan Suara (KPPS) berstatus positif Covid-19 yang tetap hadir di TPS sebanyak 1.172 TPS. "Tentu perlu diperjelas tentang situasi yang terjadi di lapangan," katanya dalam konferensi pers di Media Center Bawaslu, Jakarta, Rabu (9/12/2020) dikutip dari laman bawaslu.go.id

\section{Tinjauan Pustaka}


Perkembangan wabah pandemic secara signifikan, tidak terkecuali Indonesia menjadi negara yang terdampak wabah Covid-19. Dengan mengingat bahaya wabah tersebut, melalui mandat yang tertuang dalam pasal 12 Undang-Undang Dasar Negara Republik Indonesia Presiden kemudian menerbitkan Keputusan Presiden (Keppres) Republik Indonesia Nomor 11 Tahun 2020 tentang Penetapan Kedaruratan Kesehatan. Merujuk dalam kajian hukum tata negara darurat, penentuan keadaan darurat masih dalam lingkup staatsnoodrecht, dimana negara diwajibkan mengeluarkan kebijakan untuk menghadapi situasi darurat (Asshiddiqie, 2021). Secara teknis sebagai antisipasi penyebaran covid-19, Komisi Pemilihan Umum telah mengeluarkan kebijakan yang tertuang di dalam Keputusan KPU Nomor 179/PL.02Kpt/01/KPU/III/2020 tentang Penundaan Tahapan Pemilihan Gubernur dan Wakil Gubernur, Bupati dan Wakil Bupati, dan/atau WaliKota dan Wakil WaliKota Tahun 2020.

Apabila menganalisis dalam ketentuan peraturan perundangundangan yang termaktub dalam Undang-Undang Nomor 10 Tahun 2016 tentang perubahan kedua atas UU No. 1 Tahun 2015 tentang 'Adalah: Buletin Hukum dan Keadilan, Vol. 4, No. 1 (2020) - 124 Pemilihan Gubernur, Bupati, dan Walikota, sejatinya terdapat mekanisme yang dapat dilakukan apabila terdapat kondisi yang memaksa atau memungkinkan tahapan pemilihan kepala daerah harus ditunda. Pasal 120 Undang-Undang Pilkada menyebutkan bahwa pemilihan lanjutan adalah sebuah mekanisme penundaan pilkada yang nanti melanjutkan tahapan yang terhenti, adapun syarat ditetapkan pemilihan lanjutan, tertuang dalam pasal 120 ayat (1). Selain melalui mekanisme tersebut, adapun alternatif lain lain yaitu pemilihan susulan yang sesuai dengan Pasal 121 ayat (2) mekanisme tersebut dilakukan untuk seluruh tahapan dalam artian dimulai dari awal (Rohim, 2016).

Dalam kajian negara hukum, negara harus mampu merespon keadaan yang dimanifestasikan dalam wujud peraturan perundangan-undangan sebagai jaminan konstitutisonalitas penundaan Pilkada 2020. Secara original intens, peraturan tersebut harus mampu bertindak untuk melindungi rakyat dan menjamin kesejahteraan (Pembukaan UUD NRI Tahun 1945). Sesuai dengan adagium yang digaungkan oleh Marcus Tullius Cicero dalam karnyanya yaitu "Salus populi suprema lex esto". (Soekanto, 2002)

Hak memilih suspect covid-19, hak memilih adalah hak yang dijamin oleh konstitusi sebagimana dinyatakan dalam putusan MK nomer 011-017/puu/2003. Maka negara wajib memenuhi hak tersebut, tak lupa hak suspect covid-19. Pasien yang positif covid-19 tetap diberikan hak memilih oleh KPU berdasarkan PKPU no 6 tahun 2020. Protokol kesehatan yang diatur dalam PKPU No 6 Tahun 2020 wajib ditaati untuk menjaminkepentingan dan keselamata bersama.

\section{Pembahasan}

Sebagai negara demokrasi pemilu merupakan salah satu pesta demokrsi terbesar di Indonesia. Tetapi pada tahun 2020 Pilkada mengalami perubahan dari tahun sebelumnya, karena Pilkada tahun 2020 dilaksanakan ditengah pandemi yang sedang terjadi di Indonesia. Hal itu mengakibatkan pengunduran pelaksanaan Pilkada serentak di Indonesia. Terjadinya pelonjakan pasien yang terserang Covid-19 menjadikan masyarakat khawatir pada pelaksaan Pilkada. Berbagai reaksi muncul baik dari kalangan masyrakaat maupun pemerintah pemilu meminta agar Pilkada ditunda demi menjaga keselamatan dan keamanan masyarakat. pilkada 
di masa pandemi dikhawatirkan membuat masyarakat enggan untuk datang ke TPS karena warga takut akan tertular virus Covid-19. Hal tersebut dapat mengakibatkan kenaikan kecurangan karena masyarakat banyak yang golput, dan disalah gunakan oleh oknum yang tidak bertanggung jawab.

Pemerintah harus merespon masalah ini dengan tegas, dan harus mampu merespon keadaan dimanifestasikan dalam bentuk peraturan perundang undangan. Agar proses Pilkada dapat dilaksanakan dengan baik tanpa mengakibatkan kelonjakan angka pasien yang terkena virus Covid-19. Selain peran pemerintah masyarakat juga harus ikut menjaga protokol kesehatan dengan baik dan benar. Opini penulis adalah proses pilkada dapat tetap dilaksanakan dengan menerapkan protokol kesatan yang ketat, selain tugas pemerintah dalam proses pelaksanan Pilkada, masyarakat juga harus berkontribusi dalam kegiatan Pilkada, karena pemilu membutuhkan suara dan peran masyarakat. wabah covid-19 bukan hanya menjadi tanggung jawab pemerintah tetapi juga menjadi tanggung jawab masyarakat, pemerintah menerapkan peraturan protokol kesehatan dan tugas masyarakat adalah menaati dan melaksanakan peraturan tersebut dengan baik, karena pandemi ini kan cepat berlalu jika pemerintah dan masyarakat bisa bekerja sama dengan baik.

\section{Kesimpulan}

Pemilu adalah salah satu pesta demokrasi terbesar di Indonesia dan selalu ditunggu oleh masyarakat, karena moment ini dimana masyarakat memilih seseorang yang akan bertanggung jawab dengan segala tugas dan kewajibanya sebagai seorang pemimpin. Tetapi kita tidak pernah menduga jika akan terdapat pandemi yang dapat merubah segala kegiatan yang ada di pemerintahan dan juga masyarakat. Tetapi pandemi tersebut bukan menjadi suatu halangan untuk kita melaksanakan pesta demokrasi, dengan menaati dan mengikuti aturan yang dibuat oleh pemerintah dengan tujuan untuk kebaikan dan keselamatan bagi masyarakat. kita sebagai masyarakat hendaknya berkontribusi dan dapat bekerja sama dengan pemerintah. Selalu melaksanakan protokol kesehatan dan juga menjaga imunitas tubuh kita dapat melawan pandemi jika kita bergerak maju bersama.

\section{Daftar Pustaka}

Asshiddiqie, J. (2012). Pengantar Ilmu Hukum Tata Negara. Jakarta: Rajawali Press.

Keputusan KPU Nomor 179/PL.02-Kpt/01/KPU/III/2020 tentang Penundaan Tahapan Pemilihan Gubernur dan Wakil Gubernur, B. d. (n.d.).

Keputusan Presiden Republik Indonesia Nomor 11 Tahun 2020 tentang Penetapan Kedaruratan Kesehatan. (n.d.).

Kusumaatmadja, M. (2002). Konsep-konsep Hukum Dalam Pembangunan. Bandung: Alumni.

Pembukaan UUD NRI Tahun 1945. (n.d.).

Putusan Mahkamah Konstitusi Nomor 55/PUU-XVII/2019. (n.d.)

Rohim, N. (2016). Gagasan Pemilukada Serentak dan Implikasinya Terhadap Pesta Demokrasi yang Efektif dan Efisien. Jurnal Nanggroe, 3(3). 
Soekanto, S. (2002). Faktor-Faktor yang Mempengaruhi Penegakan Hukum, . Jakarta: Rajawali Press.

Undang-Undang Dasar Negara Republik Indonesia Tahun 1945. (n.d.).

Undang-Undang Nomor 10 Tahun 2016 tentang perubahan kedua atas UU No. 1 Tahun 2015 tentang Pemilihan Gubernur, B. d. (n.d.).

Hasibuan, R. P. P. M. (2020). Urgensitas Perppu Pilkada Di Kala Wabah Pandemi Covid-19. ADALAH, 4(1).

Dalilah, E. A. (2021). Mengikisnya Nilai Persatuan dan Kesatuan Pada Masyarakat.

Dalilah, E. A. (2021). Dampak Sampah Plastik Terhadap Kesehatan dan Lingkungan.

Siyoto, S., \& Sodik, M. A. (2015). Dasar metodologi penelitian. Literasi Media Publishing.

Setyani, A. T., \& Sodik, M. A. (2018). Pengaruh Merokok Bagi Remaja Terhadap Perilaku dan Pergaulan Sehari-hari.

Sodik, M. A. (2018, September). Analysis of Improved Attitude of Youth in HIV/AIDS Prevention through the Provision of Health Education with Peer Education. In The 2nd Joint International Conferences (Vol. 2, No. 2, pp. 495-502).

Sodik, M. A., \& Setyani, A. T. (2018). Effect of Smoking For Teens Against Behavior and Social Interaction.

Sodik, M. A. (2014). Sikap Pencegahan Aborsi Ditinjau Dari Pengetahuan Tentang Bahaya Dan Resiko Kesehatan. Strada Jurnal Kesehatan http://publikasi. stikesstrada. ac. id/wpcontent/uploads/2015/02/9-SIKAP-SIKAPPENCEGAHAN-ABORSI. pdf.

Sodik, M. A., Yudhana, A., \& Dwianggimawati, M. S. (2018). Nutritional status and anemia in islamic boarding school adolescent in Kediri City East Java Indonesia. Indonesian Journal of Nutritional Epidemiology and Reproductive, 1(3), 172-176.

TAHIN, M. W., \& Sodik, M. A. (2021). Pengaruh Merokok Bagi Remaja Terhadap Perilaku dan Pergaulan Sehari-hari.

Sodik, M. A., \& Widyastika, K. S. (2020). Analysis Completeness of Outpatient Medical Record Documents Completion Based on Motivation and Compliance with Basic Tasks and The Function of Officers. Journal of Global Research in Public Health, 5(1), 25-31.

Sodik, M. A., \& Maulina, D. (2021). Analysis Of Android-Based Online Message Gateway Towards The Use Of Plastic Bags On PKK Mother. Journal of Global Research in Public Health, 6(1), 31-37.

Sodik, M. A., Salam, D. M., \& Kardjati, S. (2020). Analysis Of Android-Based Online Message Gateway Towards The Use Of Plastic Bags. STRADA Jurnal Ilmiah Kesehatan, 9(2), 1657-1664. 
